AL-AMWAL: JURNAL EKONOMI DAN PERBANKAN SYARI'AH (tahun) (2020) Vol 12 (1): 12-21

DOI: $10.24235 /$ amwal.v1i1.5457

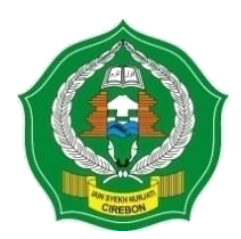

Al-Amwal: Jurnal Ekonomi dan Perbankan Syariah

ISSN: 2303-1573 e-ISSN: 2527-3876

Homepage: https://www.syekhnurjati.ac.id/jurnal/index.php/amwal email: jurnalalamwal@syekhnurjati.ac.id

\title{
Market Orientation And Product Innovation To Increase Competitive Advantages And Its Impact On Marketing Performance
}

\author{
Dikdik Harjadi \\ Master of Management Program, Universitas Kuningan, Indonesia \\ E-mail: dikdik.harjadi@uniku.ac.id
}

\begin{abstract}
Dewi Fatmasari
Syariah Banking, Faculty of Sharia and Islamic Economics, IAIN Sheikh Nurjati Cirebon, Indonesia

E-mail: dewifatmasari73@gmail.com
\end{abstract}

Ayu Siti Nurhasanah

Universitas Kuningan, Indonesia

E-mail: ayu_nurhasanah@gmail.com

\begin{abstract}
This study aims to find out the effect of market orientation and product innovation on competitive advantage in relation to marketing performance on food SMEs (Small Medium Enterprises) in Darma Sub-District, Kuningan District, West Java. By applying a total sampling method, 42 food SMEs in Darma Sub-District were selected as samples in this study. Meanwhile, the research method used in this study was descriptive-verificative method. Basically, there were thee variables in this study, namely; 1) dependent variable $(Z)$ - in this case, performance marketing; 2) intervening variable ( $Y)$ - in this case, competitive advantage; and 3) independent variable $(X)$ - which includes market orientation (X1) and product innovation (X2). The collected data were then analyzed by applying path analysis and IBM SPSS 21.0. The result showed that; 1) market orientation has a positive and significant effect on competitive advantage with value $(0,029<0,05) ; 2)$ product innovation has a positive and significant effect on competitive advantage with value $(0,000<0,05)$; 3) market orientation has a positive and significant effect on marketing performance with value $(0,045<0,05) ; 4)$ product innovation has a positive and significant effect on marketing performance with value $(0,033<0,05)$; and 5) competitive advantage has a positive and significant effect on marketing performance with value $(0.000<0,05)$.
\end{abstract}

Keyword: Market Orientation, Product Innovation, Competitive Advantage, and Marketing Performance. 


\begin{abstract}
Abstrak
Tujuan dari penelitian ini adalah untuk mengetahui pengaruh orientasi pasar dan inovasi produk terhadap keunggulan kompetitif yang berdampak pada kinerja pemasaran pada UKM makanan (Usaha Kecil Menengah) di Kabupaten Darma Kabupaten Kuningan Jawa Barat. Pengambilan sampel total digunakan sebagai metode pengambilan sampel dengan total sampel 42 UKM makanan di Kabupaten Darma o Kuningan Jawa Barat. Metode penelitian yang digunakan adalah metode deskriptif dan verifikatif. Variabel dependen (Z) dalam penelitian ini adalah pemasaran kinerja. Variabel Intervening (Y) adalah keunggulan kompetitif. Variabel independen (X) meliputi: orientasi pasar (X1) dan inovasi produk (X2). Alat analisis data yang digunakan adalah analisis jalur. Dan analisis menggunakan statistik IBM SPSS 21.0. Hasil penelitian menunjukkan bahwa orientasi pasar memberikan pengaruh positif dan signifikan terhadap keunggulan bersaing dengan nilai $(0,029<0,05)$, inovasi produk memberikan pengaruh positif dan signifikan terhadap pengaruh keunggulan bersaing dengan nilai $(0,000<0,05)$, orientasi pasar memberikan positif dan pengaruh signifikan terhadap kinerja pemasaran dengan nilai $(0,045<0,05)$, inovasi produk memberikan pengaruh positif dan signifikan terhadap kinerja pemasaran dengan nilai $(0,033<0,05)$, dan keunggulan bersaing memberikan pengaruh positif dan signifikan terhadap kinerja pemasaran dengan nilai $(0,000<0,05)$.
\end{abstract}

Kata kunci: Orientasi Pasar, Inovasi Produk, Keunggulan Kompetitif, dan Kinerja Pemasaran.

\title{
INTRODUCTION
}

Changes that are so fast these days lead to competition that can not be avoided, thus making the company faced with various opportunities and threats arising from both domestic and foreign countries, increasing competition in fighting over the market requires companies to choose and determine the right strategy in marketing their products, continue to try to understand and understand the desires of consumers, and can see market changes that occur in the business environment is one thing that companies can use to be able to compete with other companies.

The dynamic changes of business environment and consumer needs encourage companies to give their best efforts to meet these demands. As a result, the intensity of business competition in each sector increased sharply. Besides, with the rapid development of technology, every company is required to be able to adapt to the existing technology.

The competition is not only faced by large companies but also SMEs at the national level but also felt by SMEs in areas such as districts / cities and sub-districts and villages. The number of SMEs that have decreased sales results and the slow development of SMEs, shows there are problems faced by SMEs in marketing performance.

This decrease can be caused by several factors including the lack of market orientation and product innovation by SMEs. As explained by Kohli and Jaworski (1990), every company needs to establish a company's culture by strengthening market orientation in order to increase marketing performance.

Marketing performance is basically a part of company performance which is an accumulation of performance of all sectors. Marketing performance is a concept to measure the company's success in delivering its products to consumers. Meanwhile, according to Yudith (2005) in Irfannunisa et. al. (2013), marketing performance illustrates the achievement of a company as seen from the overall marketing process. This achievement can be used as a 
benchmark in assessing the success of the company in facing business competition. This is considering marketing performance in the opinion of Vos and Vos (2000) in Mustika et.al (2018) is a way to measure the success of performance on the basis of the marketing strategy that is used or it can also be said a measure of marketing achievement in corporate competition that can be measured through sales volume, sales growth and customer growth. The success of a company that is reflected by the achievements of marketing performance is the implementation of the strategy. Marketing performance is also said to be the ability of organizations to transform themselves in facing challenges from the environment with a long-term perspective.

Looking at the various shortcomings that exist in SMEs, special attention is needed to the fate of the existence of SMEs as Indonesia's real economic sector. Competitive advantage is the answer in the face of intense competition at this time, because if not then the company can not last long. In a high competitive environment, only companies that have more value will survive and survive. This is in line with the opinion of Lumkin and Dess (2005) in Irfanunnisa et.al (2013) which states that a competitive advantage exists when customers feel that a company's product has an advantage over its competitors. According to Porter (2004), an understanding is needed in looking at a company's competitive advantage as a whole; in this case, competitive advantage is an accumulation of various activities carried out by the company.

Improved marketing performance and company competitiveness can be built by developing organizational culture as values developed within the company to focus on customer/market desires (customer/market-oriented). The same conclusion was provided by Kumar (2011) that market orientation can improve the company's ability to produce cost efficiencies and new services in accordance with customer needs.

Based on the description, the following hypotheses are formulated:

1. Market orientation has a positive effect on competitive advantage

2. Product innovation has a positive effect on competitive advantage

3. Market orientation has a positive effect on marketing performance

4. Product innovation has a positive effect on marketing performance

5. Competitive advantage has a positive effect on marketing performance

\section{LITERATURE REVIEW}

Market orientation becomes a strategic aspect as it brings a company to focus and be close to its customers. This is caused by the phenomenon of competition, both locally and globally, which is very high (hight-competitive) and the rapid changes of customer needs as a result of rapid technological development (Swastha and Handoko, 2000). Hence, as stated by Grinstein (2008), market orientation as one of the important aspects must be a culture that must be implemented by each company. Basically, market orientation is the implementation of marketing concepts that offer products or services based on the needs and desires of customers.

Stanton (2012) states his view that market-oriented marketing strategies must refer to three concepts namely consumer-oriented, strive to have sales volumes that can generate profits and coordinate all marketing activities. Innovation is an action to introduce something new, both in terms of work, ideas, or other aspects, into the pattern of work that is able to make a positive contribution to the company's performance.

Wahyono (2003) argues that innovation can create competitive advantage for companies so that companies are required to develop sustainable innovation as a business strategy that can be used by companies. Simply put, innovation is often interpreted as a breakthrough/renewal related to new products. Yet, currently, innovation has a broader meaning, including the implementation of new ideas and new ways of working. Innovation can also be interpreted as a company's effort 
to adjust to rapid environmental changes so that the company is able to remain competitive with its competitors. The desire to be superior compared to its competitors is the basic thing desired by every company. Excellence is the company's ability to create "superior value" to deal with abnormal profits in industrial competition through a value creation strategy. Product innovation shows opportunities for companies to grow and develop into new areas to gain competitive advantage (Scholastica \& Maurice, 2013; Calantine, 2002; Liu.et.al, 2002). Product innovation can be interpreted as the creation of new products from new materials or changing existing products to meet consumer desires.

Generally, companies will use a competitive strategy which is divided into three general strategies, namely differentiation, cost advantage, and focus strategy. Differentiation is a strategy to offer a different offer than the offer given by competitors. Cost advantage (low cost), is a strategy of efficiency of all production costs so as to produce products or services that can be sold cheaper than competitors. Focus is a strategy to work on a specific target market. The focus strategy is usually carried out for products or services that have special characteristics (Porter, 2004). Marketing performance describes the success of a product in the area where the company competes and the success of a strategy implemented by the company. (Ferdinand, 2000) Marketing performance can be used as a parameter of success which is the accumulation of all marketing activities so that companies can also see the market achievements of the products they offer. Thus, marketing performance is a reflection of a company's performance, especially in the context of business competition.

Measurement of performance improvement with a single criterion will not be able to provide a comprehensive understanding of the actual performance of a company (Prasetya, 2002). Good marketing performance is expressed in three main quantities, namely sales value as indicated by the value of money or unit profit, sales growth as indicated by an increase in product sales, and market share as indicated by product contribution in controlling the product market compared to competitors who ultimately lead to corporate profits (Ferdinand, 2002).

Based on the description, the relationship between market orientation, product innovation, competitive advantage and marketing performance is described in the following figure.

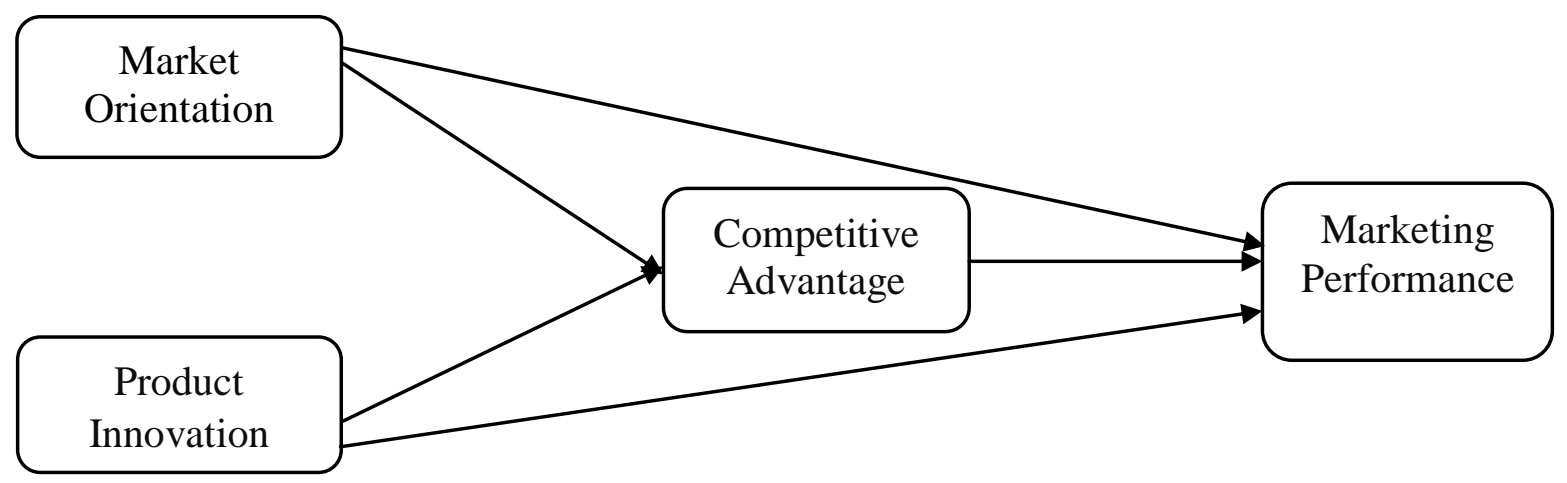

Figure 1. Thinking Framework

\section{METHODE}

In this research the method used is descriptive and verification methods. According to Sugiyono (2012: 29), descriptive method is a method for describing or explaining about a research result.

Verification method is a method used to analyze and verify the pattern of relationships between variables carried out through hypothesis testing (Sugiyono, 2009: 147). This research 
was conducted using a survey method conducted on the food sector SMEs in Darma District, Kuningan Regency. The population in this study amounted to 42 food sector SMEs, but given the relatively small population, the entire population was sampled. Data analysis method used is path analysis.

To collect the data needed, a questionnaire was distributed to the respondents. Questionnaire is a data collection tool where respondents are asked to provide answers to several questions or questions that have been determined. The questionnaire was prepared using a Likert scale where the scale size is 1 to 5 .

\section{RESULTS AND DISCUSSION Path Analysis Results}

Table 1. Model Coefficient Pathways I

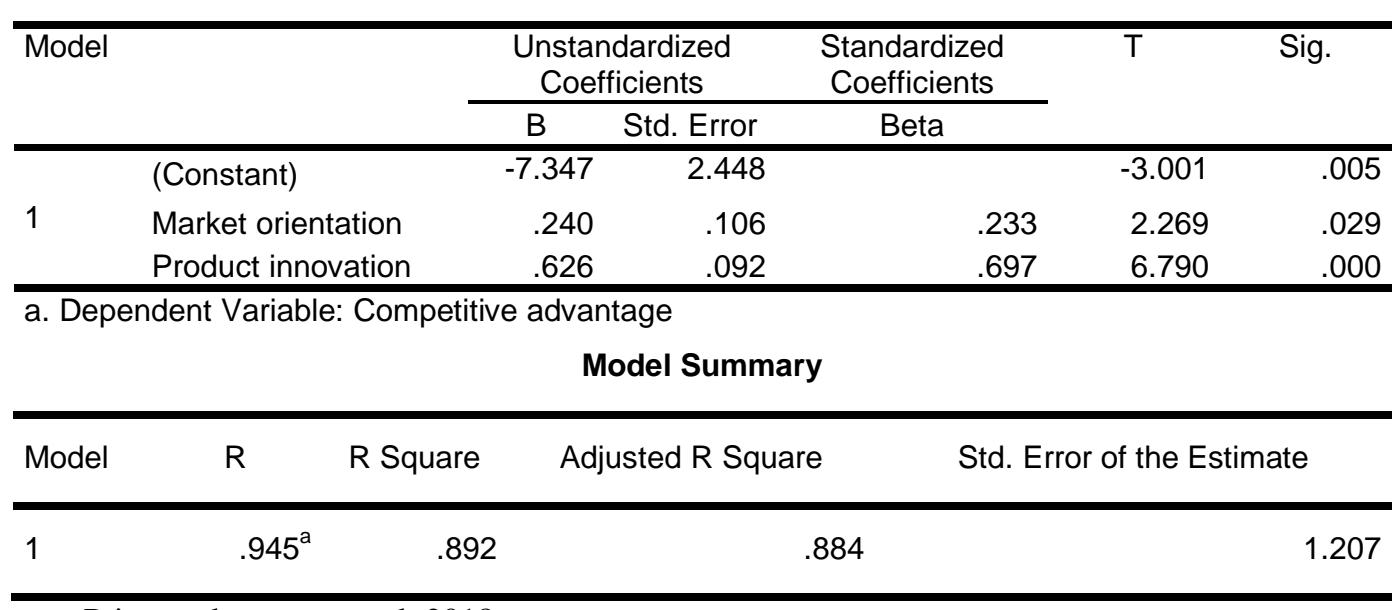

Source: Primary data processed: 2018

Table 5 shows that the significance value of the two variables namely X1 (market orientation $)=0.029$ and $\mathrm{X} 2$ (product innovation) $=0,000<$ from 0.05 . This condition illustrates that market orientation and product innovation has a positive effect on competitive advantage in which the effect of these two variables is $73.1 \%$ and the rest is influenced by other variables.

\section{Table 2. Line II Model Coefficients}

\begin{tabular}{|c|c|c|c|c|c|c|}
\hline \multicolumn{7}{|c|}{ Coefficients $^{a}$} \\
\hline \multirow{2}{*}{\multicolumn{2}{|c|}{ Model }} & \multicolumn{2}{|c|}{$\begin{array}{c}\text { Unstandardized } \\
\text { Coefficients }\end{array}$} & \multirow{2}{*}{$\begin{array}{c}\begin{array}{c}\text { Standardized } \\
\text { Coefficients }\end{array} \\
\text { Beta }\end{array}$} & \multirow[t]{2}{*}{$\mathrm{t}$} & \multirow[t]{2}{*}{ Sig. } \\
\hline & & $B$ & Std. Error & & & \\
\hline \multirow{4}{*}{1} & (Constant) & -.953 & 1.758 & & -.542 & .591 \\
\hline & Market Orientation & .099 & .050 & .178 & 1.991 & .045 \\
\hline & Product Innovation & .455 & .206 & .529 & 2.212 & .033 \\
\hline & Competitive advantage & .862 & .104 & .854 & 8.317 & .000 \\
\hline
\end{tabular}

a. Dependent Variable: marketing performance 
Table 3. Model Summary Model Summary

\begin{tabular}{lrrrrr}
\hline Model & R & R Square & \multicolumn{1}{l}{ Adjusted R Square } & \multicolumn{2}{l}{ Std. Error of the Estimate } \\
\hline 1 & $.945^{\mathrm{a}}$ & .892 & .884 & 1.207 \\
\hline
\end{tabular}

Sumber: Primary data processed : 2018

Table 6 shows that the significance value of the three variables namely X1 (market orientation $)=0.045, \mathrm{X} 2$ (product innovation $)=0.033$ and $\mathrm{Y}($ competitive advantage $)=0,000$ <from 0.05. This illustrates that market orientation, product innovation and competitive advantage have a positive effect on marketing performance. The effect of the three variables is $89.2 \%$ and the rest is influenced by other variables. The Structure Model II Diagram is presented.

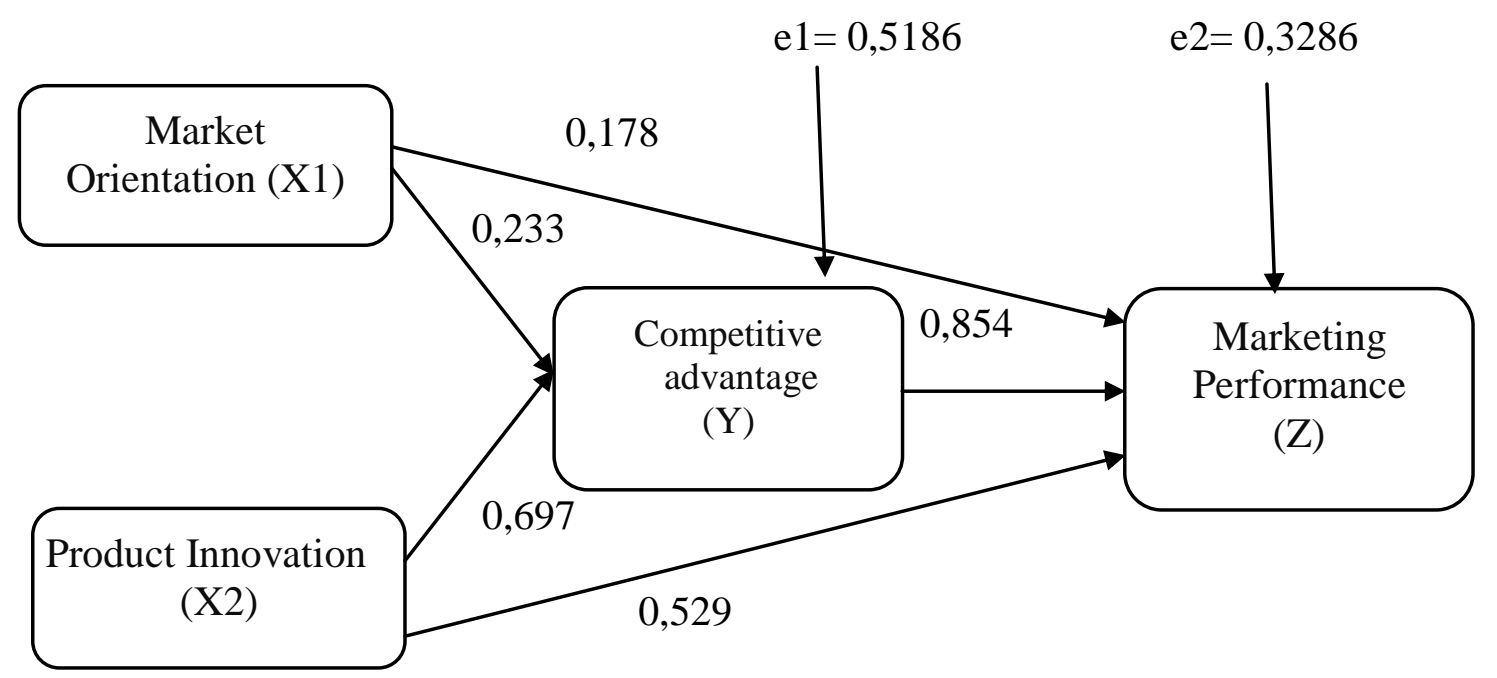

Figure 2. Analysis Path Test Results

The result of statistical tests showed that market orientation has a positive and significant effect on competitive advantage. This is obtained from the path analysis test results with a significance value of $0.029<0.05$, then the first hypothesis of this study is proven. "Market orientation has a positive effect on the competitive advantage of the Darma District Food Sector UKM"

Based on the results of statistical tests that have been carried out shows that there is a positive and significant influence of product innovation on the competitive advantage of the SME Food Sector, Darma District, this is obtained from the path analysis test results with a significance value of $0,000<0.05$, then the second hypothesis of this study is proven. "Product innovation has a positive effect on the competitive advantage of the Darma District Food Sector SMEs".

The result of statistical tests also showed that market orientation has a positive and significant effect on marketing performance. This is obtained from the path analysis test results 
with a significance value of 0.035 , this indicates a level of significance over a $(a<0,05)$. Then, the third hypothesis of this study is proven that "Product Innovation has a positive effect on the Competitive Advantage of SME Food Sector District of Darma".

Further, the result of statistical tests showed that product innovation has a positive and significant effect between on marketing performance. This is obtained from the path analysis test results with a significance value of 0.019 , this indicates a level of significance over lebih $(a<0$, 05), then the fourth hypothesis of this study is proven that "Product Innovation has a positive effect on the Competitive Advantage of SMEs in the Darma District Food Sector".

The results also showed that competitive advantage has a positive and significant effect on marketing performance, which was obtained from the results of path analysis test with a significance value of $0,000<0.05$. Thus, the fifth hypothesis is proven.

The results of statistical analysis showed that market orientation has a positive effect on competitive advantage. It means that the higher the market orientation, the higher the competitive advantage will be. In his research, Kamya et al (2010) explained that there is a positive interaction between market orientation and competitive advantage. Afsharghasemiet al. (2013) also proved the positive influence between market orientation and competitive advantage in small and medium scale manufacturing companies. An effective market orientation is meant that the company is able to meet the expectations and desires of its consumers. Thus, the greater the company's ability to meet the desires of its customers, it means that the company is superior to its competitors in meeting those desires. In other words, market orientation can be a source of competitive advantage for companies.

Product innovation as an embodiment of new thoughts and ideas in developing the products offered. The result of hypothesis testing indicates that product innovation has a positive effect on competitive advantage. The results of this study are in line with the results of Herman et. al. (2018), Scholastica \& Maurice (2013), and Puspaningrum (2017). It means that innovation is a reflection of how to create new and superior ideas to increase company's competitive advantage. This is in accordance with Suharto \& Subagja (2018) who state that innovation will make a product to remain "updated" or to stay in accordance with the needs and desires of consumers. Therefore, a company must be able to create innovation on an ongoing basis as it will create a competitive advantage for the company. As supported by Dustin, et. al. (2014), one of the important efforts to create competitive advantage is to make sustainable innovation (Herman, Hady \& Arafah, 2018).

Based on research results show that market orientation has a positive effect on marketing performance. This result is relevant to the results of research by Ghorbani, et.al (2014) which states that market orientation has a positive effect on marketing performance. The same research results from Sefnedi (2017); Jayaningrum \& Sanawiri, 2018); Mustika.et.al. (2018). Market orientation becomes important in very tight competition conditions. Therefore, market orientation seeks to focus on the needs and desires of customers which in essence market orientation will create superior value for consumers. Thus an effective market orientation will ultimately improve the company's marketing performance. When the food sector SMEs show the right market orientation, it means that the manufacture of food products is always focused on customer desires, then by itself can increase the sales volume of MSME products which in turn marketing performance of the MSME food sector will also increase. Need sensitivity and adaptive attitude to changes in customer tastes and desires that encourage MSMEs to adjust to the customer's preferences 
The results showed that product innovation has a positive effect on marketing performance. It means that the higher the innovation, the higher the marketing performance will be. It is because the innovations made by the company will give more value for the customers. Added value as a "differentiator" from competitors will encourage increased demand for products which can then increase marketing performance. The results of this study are in line with the results of research from Mustika. et.al. (2018); and Jayaningrum \& Sanawari (2018). In the context of the food sector UMKM in Darma District, Kuningan regency, the emergence of product innovations made by MSME actors has led to variations and alternative choices for buyers who have an interest in buying. The innovations made include many things such as types of food, taste, packaging, processing techniques, quality and price. Product innovation becomes increasingly important when there are dynamic changes in customer behavior and desires and tastes. Finally, product innovation encourages food products to be offered and will encourage customer appeal, which in turn can also drive marketing performance.

Competitive advantage as a company's value over competitors has a positive effect on marketing performance. This shows that when the food sector UMKM has a high competitive advantage it will be able to improve its marketing performance. These results are in line with the results of research Herman, et.al. (2018) which states that competitive advantage has a positive and significant effect on company performance. Companies that have a competitive advantage in their business activities will show better performance. In other words, that competitive advantage will be able to improve marketing performance. This was confirmed by Porter (1990) who stated that competitive advantage was the main aspect in the company's performance to face competition. Also supported by the opinion of Hasan (2014) which explains that competitive advantage is the main key to superior long-term business performance.

\section{CONCLUSION}

Based on the analysis, it can be concluded that; 1) market orientation has a positive and significant effect on competitive advantage. It means that the more effective the Market Orientation, the higher the competitive advantage will be; 2 ) product innovation has a positive and significant effect on competitive advantage. It means that the higher the market innovation, the higher competitive advantage will be; 3) market orientation has a positive and significant effect on marketing performance. It means that the more effective the market orientation, the higher the marketing performance will be; 4) product innovation has a positive and significant effect on marketing performance. It means that the higher the product innovation, the higher the marketing performance will be; and 5) competitive advantage has a positive and significant effect on marketing performance. It means that the higher the competitive advantage, the higher the marketing performance will be.

\section{REFERENCES}

Akbar, A., Zain, M., Sambasivan, M., \& Imm, S. S. (2013). Market orientation, government regulation, competitive advantage and internationalization of SMEs: A study in Malaysia. Jurnal of Business Administration Research, 2(2).

Calantine, R J., Cavusgil, \& Zhao, Y. (2002). Learning orientation, firm innovation capability and firm performance. Industrial Marketing Management, 3(1).

Dustin, G., Bharat, M., \& Jitendra M (2014). Competitive advantage and motivating innovation. Advance in Management, 8(1). 
Ferdinand, A. (2000a). Manajemen pemasaran: Sebuah pendekatan strategy. (Unpublished thesis). Program Magister Manajemen Universitas Diponegoro.

Ferdinand, A. (2000b). Structural equation modelling dalam penelitian manajemen. Semarang: Pustaka Kunci.

Ghorbani, H., Dalvi, M. R., \& Hirmanpour, I. (2014). Studying the effect of market orientation on marketing effectiveness: A Case study. IJARBSS, 4(1).

Grinstein, A. (2008). The relationships between market orientation and alternative strategic orientations A meta-analysis. European Journal of Marketing, 42(1/2), 115-134.

Herman, H., Hady, H., \& Arafah, W. (2018). The influence of market orientation and product innovation on the competitive advantage and its implication toward small and medium enterprise performace. International Journal of Science and Engineering Invention, 4(8).

Irfanunnisa, T., \& Hartanti, R. (2013). Peningkatan kinerja pemasaran melalui optimalisasi keunggulan bersaing. Jurnal EKOBIS, 14(2).

Jayaningrum, E., \& Sanawiri, B. (2018). Pengaruh orientasi pasar, inovasi, orientasi kewirausahaan terhadap keunggulan bersaing dan kinerja pemasaran. Jurnal Administrasi Bisnis, 54(1).

Kamya, M. T, Ntayi, J. M., \& Ahiauzu, A. (2010). Knowledge management and competitive advantage: The interaction effect of market orientation. African Journal of Business Management, 4(14), 2971-2980.

Kohli, A. K., \& Jaworski, B. J. (1990). Market orientation: The construct research proposition, and managerial implication. Journal of Marketing, 7(2).

Kumar, V., Jones, E., Venkatesen, R., \& Leone, R. P. (2011). Is market orientation a source of sustainable competitive advantage or simply the cost of competing? Journal of Marketing, $75(1)$.

Liu, S., Luo, \& Shi, Y. (2002). Integrating customer orientation in organization in transitional: An empirical study. International Journal of Business Research in Marketing, 19(3).

Medhika, G., \& Yasa. (2018). Peran keunggulan bersaing dalam memediasi orientasi pasar dan orientasi kewirausahaan dengan kinerja UKM. INOBIS: Jurnal Inovasi Bisnis dan Manajemen Indonesia, 1(2).

Mustika, D. A., Wahyuni, S., \& Widodo, J. (2018). Pengaruh orientasi pasar dan inovasi produk terhadap kinerja pemasaran. Jurnal Pendidikan Ekonomi, 13(2).

Narver, J. C., \& Slater, S. F. (1990). The effect of market orientation on business profitability. Journal of Marketing, 4(1).

Porter, M. E. (2004).Competitif strategy. New York: The Free Press.

Prasetya, D. I. (2002). Lingkungan eksternal, faktor internal, dan orientasi pasar pengaruhnya terhadap kinerja pemasaran. Jurnal Sains Pemasaran Indonesia, 1(3), 219-240.

Puspaningrum, A. (2017). The effect of market orientation and innovation on competitive advantage. Research Journal of Business and Management, 4(4).

Scholastica, E., \& Maurice, I. (2013). The relationship between market orientation firm, innovativeness and business performance of companies in Nigeria. International Journal of Asian Social Science, 3(11).

Sefnedi. (2017). The market orientation and performance relationship: The empirical link in private universities. Jurnal Manajemen dan Kewirausahaan, 19(1).

Stanton, W. J. (2012). Prinsip Pemasaran. Terj. Lamarto, Y. Jakarta: Erlangga.

Sugiyono. (2012). Metode Penelitian Bisnis. Bandung: Alfabeta. 
Suharto, \& Subagja, I. K. (2018). The influence of market orientation and entrepreneurial orientation to competitive advantage through business innovation: Study on Batik Trusmi Cirebon West Java Province Indonesia.

Supriyanto, A., Sukrina, H. R., \& Abidin, M. Z. (2017). Pengaruh orientasi pasar dan inovasi produk terhadap keunggulan bersaing. Prosiding Seminar Nasional AIMI, 27-28 Oktober 2017.

Swastha, B. (2000). Manajemen Pemasaran Modern (Edisi Kedelapan). Yogyakarta: Liberty.

Wahyono. (2003). Orientasi pasar dan inovasi: Pengaruhnya terhadap kinerja pemasaran. Jurnal Sains Pemasaran Indonesia, 1(1). 